\title{
CORRELATION BETWEEN STUDENTS' VOCABULARY MASTERY AND STUDENTS' SPEAKING ABILITY AT VIII GRADE OF SMP NEGERI 4 GAUNG ANAK SERKA
}

\author{
Trinovangke Fatimah ${ }^{1}$, Agus Mustajib ${ }^{2}$, Sri Erma Purwanti ${ }^{3}$ \\ English Study Program \\ Universitas Islam Indragiri - Tembilahan Riau ${ }^{1,2,3}$
}

\begin{abstract}
The purpose of this study was to investigate the correlation between students' vocabulary mastery as the independent variable and speaking ability as the dependent variable. The sample of this study were 38 students of eighth-grade students of SMPN 4 Gaung Anak Serka. The research method used in this study was a correlation study. The researcher gave tests of vocabulary and speaking ability to collect data. After the data has been collected, it was found that the average of students' vocabulary mastery is 42.7 , it was in the very low category, and the average of students' speaking ability was 36.5 , also in the very low category, it was in the range $00-49$. Based on those findings, the researcher analyzed the relationship between the students' vocabulary mastery and speaking ability using the Pearson Product Moment formula, the results was 0.339 it was classified as low correlation. Then to test the hypothesis, the researcher compared the values of $r_{x y}=0.339$ and $r_{\text {table }}=0.2709(5 \%)$ and $0.3202(1 \%)$. In short, $0.2709<$ $0.3393>0.3202$. Meanwhile, the SPSS result has also proven that the Sig. (2-tailed) was 0.037 , which was less than 0.05 . Dealing with the results, it could be determined that $\mathrm{H}_{\mathrm{o}}$ (null hypothesis) was rejected, and $\mathrm{H}_{1}$ (alternative hypothesis) was accepted. It means that there is a positive and significant correlation between vocabulary mastery and speaking ability. If students have good vocabulary so that they will have a good speaking ability
\end{abstract}

Keywords: Vocabulary mastery, speaking ability

\section{INTRODUCTION}

English is an international language, the meaning of another word English is the unifying language between one country and another to communicate. Learning English has four skills that are writing, speaking, reading and listening. In learning English most students have difficulty, one of which is difficulty in speaking. Speaking then there are more skills such as fluency, pronunciation, intonation and so forth.

Speaking is an intransitive process of constructing meaning that involves producing and receiving and also processing information (Brown, 1994; Burns \& Joyce, 
1997). The form and meaning depend on the context where occurs, including the participants themselves.

SMP N 4 GAS is one of the Junior High School uses K13 (2013 curriculum). In this study, the researcher will focus on one skill that is speaking. Some problems are faced by the students who have not mastered vocabulary, cannot pronounce vocabulary properly and correctly, difficulty to express ideas verbally and lack of courage to speak.

The first problem is the students have not mastered vocabulary. It is one of the problems that every student has; this can be seen from students speaking. This problem is also caused by students who lack the enthusiasm and attractiveness of learning English very much. Even though the more vocabularies a person has, the better the person's speaking ability. Besides this vocabulary mastery must be trained early so that they can be trained and have good skills in speaking.

The second problem is the students cannot pronounce vocabulary properly and correctly. It is caused by the unfamiliarity of the foreign language. The solution has to get used to listening and speaking foreign languages to make our mouth and tongue easy to pronounce.

The third problem is the students' difficulty to express ideas. In addition to good vocabulary mastery and pronunciation, it turns out that expressing ideas that are orally is not an easy thing, because it must have the insight to develop the ideas we have. If we have ideas and broad insights, then automatically we also speak very easily and smoothly. The solution to this problem is to practice to express ideas.

The last problem is the lack of courage to speak. Courage is the main key in speaking, why is it said so because it is useless if you have a good idea, broad insight, and good vocabulary pronunciation and can also master a lot of vocabulary but can't express what we have. The solution to this problem is by having to mentally train and be courageous in front of crowded people to get used to the situation. 


\section{LITERATURE REVIEW}

\section{Vocabulary Mastery}

Vocabulary is commonly defined as knowledge about the word, words meaning, and word usages to express their idea through oral or written communication. Language has many vocabularies that are combined to become meaningful unity. Vocabulary is used as the first step to recognize language deeper. Someone who has good mastery in vocabulary can understand more in communication. On the contrary, someone who weak in vocabulary mastery will get difficulty when communication both oral and written language.

According to Nuna (1999: 101), vocabulary is more than lists of target language words. Since vocabulary is a list, the only system involved is that alphabetical order. It also needs the process of learning in context to get the meaning of words. Also, Aisyah (2016: 9) also defines that vocabulary is all about words. In this case, vocabulary is an essential and basic component of all users of the English language. When learners acquaint new vocabulary, they must know the meaning of words. The words will useful if it used a certain language. The learners also must know to arrange individual word meaning within the sentence. From the definition above, it can be concluded that vocabulary is the knowledge of the total number of words, a list or a set of words in a particular language that a person knows or uses. It must be learned by foreign language learners aimed to find out the meaning for certain purposes. They will be easy in learning language because of the role of vocabulary. The lacking of vocabulary causes difficulties in the learning process for the learners.

There are some indicators of vocabulary mastery

1. Students can determine the form of a word

In learning English, one of the most important things is knowing and understanding the parts of the speech. Speech parts are types of words. According to the (Aby Andaya Iswara (2016: 19). simplest English rules, there are 8 (eight) types of words in English; Noun is used to name people, objects, animals, places, and abstract concepts, Pronoun is used to replace a noun. This part of speech is useful to avoid repetition of noun usage, Verb is used to show actions from the subject, indicate events, or circumstances, Adjective is used to explain noun or pronoun, Adverb is 
used to explain verb, adjective, or another adverb. A preposition is combined with nouns or pronouns, forming phrases that explain verb, noun, or adjective, Conjunction is used to connect two words, phrases, clauses, or paragraphs. This word is divided into coordinate, correlative, subordinate, and adverbial conjunction, and Interjection is a short speech used to express emotions.

2. Students can determine the meaning of words.

In learning English, of course, we are still confused with the meaning of the vocabulary. Therefore students must be able to interpret each word in the sentence.

3. Students can use the words inappropriate context.

Context can help a person to understand ideas in the text while increasing vocabulary. Kustaryo (1988: 23) states that "isolated words often do not provide meaningful meaning. Words have different meanings depending on the context.

\section{Speaking Ability}

Speaking is a communication process that is a primary medium to express ideas. Many experts believe that speaking is a media to interact with the surrounding people in terms of sharing ideas and releasing problems. Soelaiman (2007: 112) abilities are traits that are born or learned that allow someone who can complete their work, both mentally and physically. Employees in an organization, although well-motivated, but not all can work well. Abilities and skills play a major role in individual behavior and performance. Skills are skills that relate to the tasks that are owned and used by someone at the right time. According to Stephen P. Robins (2006.46) ability is the capacity of individuals to carry out various tasks in certain jobs. The ability of an individual is essentially composed of two factors, namely intellectual ability and physical ability.

The purpose of speaking as has been mentioned earlier that speaking is a tool to convey information with other people for certain reasons. Harmer (1985: 41) claims that there are some generalizations can be generated as the reasons why someone speaks, as in the following; he wants to speak that meaning may be forced on him in some ways, he has some communicative purpose, for instances charming the listeners, sharing information or expressing pleasure. It sometimes could be decided to be rude or to 
flatter, to agree or to complain, and he selects from his language store which means that he might have an infinite capacity to create new utterances if he is a native speaker.

There are some indicators of speaking ability. Firstly, pronunciation is a difficult component in learning the ability to speak English. The pronunciation itself is defined as the way the word is pronounced. Oxford Advanced Leaner's Dictionary (1995: 928). Secondly, vocabulary is all about words. In this case, vocabulary is an essential and basic component of all users of the English language. When learners acquaint new vocabulary, they must know the meaning of words. The words will useful if it used a certain language. The learners also must know to arrange individual word meaning within the sentence. Aisyah (2016: 9). Thirdly, fluency is defined as the ability to speak communicatively, fluently and accurately. Fluency usually refers to express oral language freely without interruption. In the teaching and learning process, if the teacher wants to check students' fluency, the teacher allows students to express themselves freely without interruption. The aim is to help students speak fluently and with ease. The teacher does not correct immediately whereas the idea being that too much correction interferes with the flow of conversation. Pollard ( 2008: 16). Lastly, comprehension is to include those objectives, behaviors or responses which represent an understanding of the literal message contained in a communication. Bloom Benyamin in Ridwan (2016: 29).

\section{The Correlation between Mastering Vocabulary and Speaking Ability}

Vocabulary mastery and speaking ability have a close correlation with each other since vocabulary is a branch of speaking skill. It is also a foundation to construct better speaking ability which has a relationship to other language aspects, such as spelling, pronunciation, structure and many others. It is therefore essential for students to master vocabulary to acquire any language skills proficiently.

What is more, the acquisition of an adequate vocabulary is essential to be a success at a second language used since without an extensive vocabulary, it is impossible to apply the structure of the language and its functions. The more vocabulary develops, the easier to add new words even though the first ten words are probably the 
most difficult to learn. Nunan (1991: 117). Concerning this issue, Nunan (1991:122) also emphasizes that it is important to the local government.

Al - Kufaisi (1988:42), furthermore, states that: In communication, the most important items that have to be mastered by English language learners are vocabularies, because they will not be able to state their ideas with limited vocabularies. It has become a major problem in speaking or interacting with others, for example, how to understand the news or cast on the radio, TV and other media if they have limited vocabulary. Based on the description above, it can be assumed that there is a close correlation between mastering vocabulary and speaking ability.

\section{RESEARCH METHOD}

It was designed by using correlational research. The basic correlational research design is not complicated. Two (or more) scores are obtained for each member of the sample, one score of each variable of interest, and the paired scores are are correlated. The result is expressed as a correlation coefficient that indicates the degree of relationship between the two variables, and some utilize complex statistical procedures, but the basic design is similar in all correlational studies. L.R Gay (2000: 321)

The samples of the research are all of the VIII grade students SMP Negeri 4 Gaung Anak Serkawith the total number is 38 students. The sample is divided from total and characteristic that have by population (Sugiono, 2009: 62). Because the students are less than 100 students, the writer keeps choosing the sample $100 \%$ population as a sample.

Moreover, the researcher used two kinds of tests for collecting the data. Oral Test, it is a form of test that demands a response from a child in the form of spoken language (Arifin, 1988: 37). It is done to determine the students' speaking ability involving their pronunciation, grammar, vocabulary, fluency, and comprehension. The type of oral test used in this research is monolog. Vocabulary Test, 30 questions must be answered by the students. Since the list of vocabulary to the eighth grade is too large, the writer will take 10 vocabularies as representative of each indicator. The duration time for doing the test is 60 minutes. It is about 2 minutes for each question. 
Then the researcher analyzed the corpus to determine their achievement tests both speaking ability and vocabulary mastery. To gain the students' score from the test by the following formula:

$$
P=\frac{X}{N} \times 100
$$

$\mathrm{P}=$ Individual score

$$
\mathrm{X}=\text { Correct Answer } \quad \mathrm{N}=\text { Number of items }
$$

In determining the students' speaking ability in this research, the researcher utilized oral test. The test is evaluated by criteria recommended. There are four criteria involving namely; pronunciation, vocabulary, fluency, and comprehension. After getting the data, the students' scores would be classified into the following levels:

Table 1 The Classification of Students' Score

\begin{tabular}{|c|c|}
\hline Students' Score & Categories of Score \\
\hline $80-100$ & Very Good \\
\hline $70-79$ & Good \\
\hline $60-69$ & Enough \\
\hline $50-59$ & Low \\
\hline $00-49$ & Very Low \\
\hline
\end{tabular}

(Suprayekti et al, 2005: 13in Siti Aisyah 2016: 31)

In determining the correlation coefficient, the researcher used Pearson Product Moment correlation analysis manually as well as using the SPSS program. The results might be classified into five categories as below (Sodijono, 2004: 193):

Table 2 Interpretation of Correlation Coefficient

\begin{tabular}{|c|c|}
\hline $0.00-0.20$ & Very low correlation \\
\hline $0.21-0.40$ & Low correlation \\
\hline $0.41-0.70$ & Moderate correlation \\
\hline $0.71-0.90$ & High correlation \\
\hline $0.91-1.00$ & Very high correlation \\
\hline
\end{tabular}

\section{FINDINGS AND DISCUSSION}

The purpose of the data analysis in this research is meant to measure the significant correlation between the students' mastery of vocabulary and their speaking ability the eighth-grade students of SMPN 4 Gaung Anak Serka.

\section{The students' vocabulary mastery}


After collecting the data, the researcher could determine the students' vocabulary mastery. The data were displayed as follow:

Table 3 The students' vocabulary mastery

\begin{tabular}{|c|c|c|c|}
\hline Students' Score & Categories of Score & Frequency & Percentage \\
\hline $80-100$ & Very Good & 0 & 0 \\
\hline $70-79$ & Good & 1 & 2.6 \\
\hline $60-69$ & Enough & 2 & 5.4 \\
\hline $50-59$ & Low & 6 & 15.7 \\
\hline $00-49$ & Very Low & 29 & 76.3 \\
\hline \multicolumn{2}{r}{ Total } & 38 & 100 \\
\hline
\end{tabular}

Referring to the data on the table, it could be known that the students' vocabulary mastery was varied. None of the students got a very good level. Then only two students $(5.4 \%)$ were placed in enough level. Six students $(15.7 \%)$ obtained a low level. Last, more than half of the total of the students got a very low category. It could be implied that the students still had insufficient vocabulary mastery.

\section{The students' speaking ability}

After distributing the instruments to the respondents, the researcher could find the students' speaking ability. The data were presented as below:

Table 4 The students' speaking ability

\begin{tabular}{|c|c|c|c|}
\hline Students' Score & Categories of Score & Frequency & Percentage \\
\hline $80-100$ & Very Good & 0 & 0 \\
\hline $70-79$ & Good & 1 & 2.6 \\
\hline $60-69$ & Enough & 2 & 5.4 \\
\hline $50-59$ & Low & 3 & 7.9 \\
\hline $00-49$ & Very Low & 32 & 83.9 \\
\hline \multicolumn{2}{r}{ Total } & 38 & 100 \\
\hline
\end{tabular}

Concerning the empirical information above, it was seen that the students' speaking ability was varied. No one of the students was in a very good category. Next, there was only one student (2.6\%) who had the ability at a good level. Two students $(5.4 \%)$ were classified in enough level. Moreover, there were three students $(7.9 \%)$ who were at a low level. Then thirty-two students got a very low category. It could be determined that the students still had the incompetent speaking ability. 


\section{Correlation between the students' vocabulary mastery and speaking ability}

The next step of the analysis data was to find the correlation between the variables investigated; vocabulary mastery $(\mathrm{X})$ and speaking ability (Y). The researcher used the SPSS as well as manual analysis. The results were as in the following.

Table 5. Correlation between the students' vocabulary mastery and speaking ability

\begin{tabular}{|ll|r|r|}
\hline & & Vocabulary Mastery & Speaking Ability \\
\hline Vocabulary Mastery & Pearson Correlation & 1 & $.339^{*}$ \\
& Sig. (2-tailed) & & .037 \\
\hline Speaking Ability & Pearson Correlation & $.339^{*}$ & 1 \\
& Sig. (2-tailed) & .037 & \\
\hline
\end{tabular}

*. Correlation is significant at the 0.05 level (2-tailed).

a. Listwise $\mathrm{N}=38$

By noting the result of the formula of $r_{\text {calculated }}(0.339)$, it is found that the index is in the interval of $0.21-0.40$ which means that between variable vocabulary mastery and speaking ability was in a low correlation.

Then it was also noted to the table of degree of freedom (df) $\mathrm{N}$ (number of respondents) $-\mathrm{nr}$ (variables) where $38-2$ is 36 . By consulting with $\mathrm{r}_{\text {table }}$ productmoment, it is found in the table of significant of $1 \%$ is 0.2709 and $5 \%$ is 0.3202 . By comparing the values of $r_{x y}=0.339$ and $r_{\text {table }}=0.2709$ and 0.3202 , the researcher

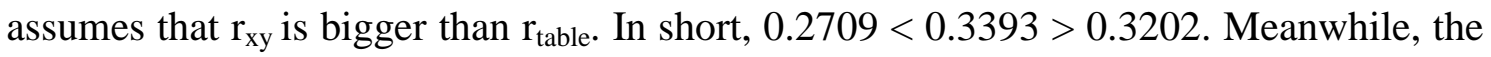
SPSS result has also proven that the Sig. (2-tailed) was 0.037, which was less than 0.05. Dealing with the results, it could be determined that $\mathrm{H}_{\mathrm{o}}$ (null hypothesis) was rejected, and $\mathrm{H}_{1}$ (alternative hypothesis) was accepted. It means that there is a positive and significant correlation between vocabulary mastery and speaking ability.

\section{CONCLUSION}

Speaking and vocabulary correlate. The students have many vocabularies; it can help students to be better in speaking ability. Vocabulary is one important aspect of learning a foreign language. With a limited vocabulary, anyone will also have limited understanding in terms of speaking, reading, listening and writing. It is true that is might be impossible to learn a language without mastering vocabulary. Mastering vocabulary 
is the ability to get or to receive a lot of words. Students have many vocabularies that can make students understand what a teacher says and students can make a conversation with someone. Speech cannot be produced without vocabulary and vocabulary is indispensable to speaking performance. Furthermore, in facts based on the data described in this research, the researcher concludes that the eighth grade of SMPN 4 GAS students' vocabulary mastery and speaking ability is in moderate significant correlation. It means the students' vocabulary mastery is enough to help speaking ability become well in short, the better their vocabulary mastery the higher speaking ability.

\section{REFERENCES}

Afrizal. (2005). The Students Strategies in Memorizing English Vocabulary at The Second Year Students of Abbasyiah Senior High School Teluk Pinang Indragiri Hilir. Unpublished S1 Degree's Thesis. Teluk Pinang : Fakultas Keguruan dan Ilmu Pendidikan UNISI.

Aisyah, Siti. (2016). The Correlation Between Students'Vocabulary Mastery And Their Speaking Ability at Grade VIII Students of SMPN 1 Tembilahan Hulu. Unpublished S1 Degree's Thesis. Tembilahan: Fakultas Keguruan dan Ilmu Pendidikan UNISI.

Darwish and Abdul. (2014). A Correlational Study between Vocabulary Mastery and Reading Comprehension of Pai Students OfTarbiyah Stain DatokaramaPalu, 2 $\begin{array}{llll}\text { Retrieved } & \text { Agustus } & \text { 2018, }\end{array}$ http://www.jurnal.iainpalu.ac.id/index.php/ist/article/view/240/166

Dinihari, Eka Putri, et al. (2008). The Application of Reporting Back Strategy to Increase the Speaking Ability of The Second Grade Students of SMPN 1 Duri in Recount Text. Pekanbaru: University of Riau.

Gay LR and Airasian. (2000). Educational Research. Columbus: Practice Hall.

Hafitsa. M, Nisa. (2010). Improving The English Speaking Skills of The Students by Using "Paikem" Approach With Use in Focus Media. Bogor: Inkhaldun University Bogor.

Hornby, A.S. (2005). Oxford, Advanced Leaner's Dictionary. Oxford University Press: New York.

Isroin, Nurlia. (2009). A Study on The Learning Strategies Used by The First Year Students at SMPN 1 Srengat Blitar. Unpublished S1 Degree's Thesis. Srengat Blitar: Fakultas Keguruan dan Ilmu Pendidikan UNISI. 
Iswara, Aby Andaya. et al. (2016). Improving Students' Speaking Fluency Through the Inplemantion of Trivia-Based Activity in University Students. Journal of Seblas Maret University, 5. 23 July 2018, from http;//www.60183-ENimproving-students-speaking-fluencythro.html

Jaffe, Clella Iles. (2011). Public Speaking, $7^{\text {th }}$ Edition.

Khosy, Valsa. (2005). Action Research for Improving Practice. London: Paul Chapman Publishing.

Lepoleli, Triliza. (2008). The Influence of Vocabulary Mastery in Speaking Ability at the Second Year Students of English Education Departement of Uin Suska Riau, Pekanbaru.

Marisya, Renny. (2017). The Students' Strategies In Memorizing English Vocabulary at The Second Years Students of MTsN Tembilahan. Unpublished S1 Degree's Thesis. Tembilahan: Fakultas Keguruan dan Ilmu Pendidikan UNISI.

Rahmawati, Rita. (2010). The Effect of Short Dialogue Memorizing Toward Students Speaking Ability at The Second Years Students of SMPN 8 Pekanbaru: Uin Suska Pekanbaru.

Richards, Jack C. (2000). Vocabulary in Language Teaching. America: The United States of America.

Rusefandi. (1993). Statiska Untuk Penelitian Pendidikan. Jakarta: Dapartemen Pendidikan dan Kebudayaan Dikroterat Jendral Perguruan Tinggi Proyek Pembinaan Tenaga Kependidikan Perguruan Tinggi.

Sugiono. (2008). Metode Penelitian Kuantitatif Kualitatif dan R\&D. Bandung: Alfabeta.

Sukardi. (2004). Metodologi Penelitian Pendidikan Kompetensi dan Praktiknya. Jakarta: Bumi Aksara.

Syamsudin and Vismaia. (2009). Penelitian Pendidikan Bahasa. Bandung: PT Remaja rosdakarya.

Syamsudin, dkk. (2011). Metode Penelitian Pendidikan Bahasa. Bandung: PT Remaja rosdakarya.

Thornbury, Scoot. (2002). How to Teach Speaking. Inggris: Pearson Longman. 